\title{
Reducing the Intensity of Students Bullying Toward Children with Special Needs Using Puppet Show
}

\author{
Andromeda \\ Psychology Department \\ Universitas Negeri Semarang, Indonesia \\ andromeda@mail.unnes.ac.id
}

\author{
Aiza Fitri Hardianti \\ Psychology Department \\ Universitas Negeri Semarang, Indonesia \\ andromeda@mail.unnes.ac.id
}

\begin{abstract}
Bullying does not only occur in general schools, but also in inclusive schools and the victims are children with special needs. One of the factors is the lack of students' knowledge about children with special needs, causing misperceptions of special need children's behavior. This study aims to determine the effectiveness of psychoeducation-based intervention techniques with puppet show to reduce the intensity of student bullying towards children with special needs in inclusive school. This research is an experimental study with a one-group pretest-posttest design research design. The research subjects used in this study were nine students. They come from the entire population based on predetermined characteristics. The treatment was given in three times. Pretest was given before treatment and post-test after treatment. The data was collected by three observers using a rating scale of bullying behavior. The results showed that there were differences in the intensity of bullying behavior between pre-test and post-test, which means puppet show were effective in reducing student's bullying behavior towards children with special needs in inclusive school.
\end{abstract}

Keywords: puppet show, bullying, special need children, inclusive school

\section{INTRODUCTION}

According to Sumekar (in Anggraini, 2013), children with special needs are those who experience disorder or disability in physical, mental, emotional and social or the combination of those aforementioned so they need special education service adjusted to their disorder or disability. There are two kinds of students with special needs education which are exclusion (school for exceptional children) and inclusion (joining normal children). Elementary school has around eight students with special needs. The inclusion there has been implemented since 2004 where students with special needs learn together with normal students. One of the advantages in the inclusion education is that children is that children can learn to accept differences and able to adapt with those differences. However, in fact there are students who have not been able to adapt with those students with special needs therefore they do bully to those different friends.

Olweus (in Wiyani, 2012) stated that "bullying occurs when one does an action of hurting other person and does it repeatedly". Bullying could be in form of physical contact, verbal or action. Lack of knowledge about those with disability caused the misunderstanding and negative behavior towards them. Not only adults who misunderstood, but also children of four or five years old have developed misunderstanding and negative behavior towards individuals with disability and continued to be characteristic of elementary school children (Dunst, 2012). Moreover, according to Astuti (2008) one of the factors that bullying occurs is that there is a value misperception towards victim's behavior. Students at school do not really know and understand how to treat those different friends therefore the do bullying towards their disabled friends.

Puppet show is one of the medias in intervention based on psychoeducation. According to Supratiknya (2016) psychoeducation basically is open to anyone, either children, teenagers or adults, individual or group. Several psychoeducation theories are developed from learning theory. Both explain about how to raise expected behavior and eliminate unexpected behavior. Medias in psychoeducation are various, such as video, picture or poster, song, puppet etc. The selection of the media used in psychoeducation is adjusted to the age of the research subject. Gagne dan Briggs (in Sulianto, 2015) asserted that elementary school students have concentration span in average of 5-8 minutes to listen to story. Therefore, in telling story, it is better to use exciting media like puppet show. Puppet show as a story media has many advantages. Children in general like puppet, thus the story told by the puppet characters will attract their interest and attention. Children can also be involved in the puppet game by playing the role of the puppet. This means that puppet could be the attention attract for the children as well as a media to express or show the feelings.

In addition, in a study by Braga et al (2011), on an intervention using children's stories, it was found that group storytelling could be a beneficial tool for performing nursing measures and improving mental health among children. Moreover, a study by Homaei et al (2009), with the aim of determining the effects of storytelling on children's adaptability, indicated that there was a significant difference between the adaptive behaviors' scores of the children in the experimental and control groups.

\section{METHOD}

This study is experimental research with one-group pretest-posttest design. In this design, there are two measuring by doing pretest (before treatment) and posttest (after treatment). Pretest is used to know the subject's 
initial condition before the treatment and posttest is used to know the subject's condition after treatment. Subjects in this experimental research are nine students showing bullying behavior on students with special needs. Bullying are shown by three dimensions namely: physical (pinching, punching, pushing, hitting, forcing, pulling hair, kicking); Verbal (mocking, calling name, swearing, offending, gossiping); and psychological (excluding, synical, ignoring, intimidating). Three observers were involved in the data collection using bullying's rating scale. The steps in experiment process are as follow:

\section{Initial step}

The initial step of the experiment was giving pre-test to the experiment group. This pre- test itself is aimed to take initial data as the reference later in comparing the post test results in the final step. The pre-test was in form of observation conducted one day at school to see the intensity of bullying behavior occurred. In the next meeting, the researcher gave socialization about children with special needs and bullying behavior to give preliminary introduction to the students.

\section{Psychoeducation with puppet show media}

The main step of the experiment in this research is giving intervention to research subject. The intervention conducted here is psychoeducation using puppet show media. Puppet show would be given in 3 meetings of 120 minutes each session. The method used is telling story about bullying behavior on children with special needs. The story is about the bullying behavior on children with special needs and how to minimize the bullying behavior. The story material was adapted from PACER's National Bullying Prevention Center - PACER Center (https://www.pacer.org/bullying).

\section{Final Step}

After the intervention was given, the next step was giving the post test. Giving posttest is aimed to see whether there is a declining intensity of bullying behavior after the treatment of psychoeducation using puppet show media. The post test was conducted to see how effective the treatment given. The flow of the experiment in this research is explained in the scheme as follow (Table 1).

Table 1

Experiment Flow

\begin{tabular}{|c|l|l|l|l|}
\hline Meeting & \multicolumn{1}{|c|}{ Activity } & \multicolumn{1}{|c|}{ Technique } & \multicolumn{1}{c|}{ Time } & \multicolumn{1}{c|}{ Material } \\
\hline 1 & Pretest & Observation & 8,5 hours & Observation sheet, handycam, writing tools \\
\hline 2 & $\begin{array}{l}\text { Socialization / Education about children } \\
\text { with special needs and Bullying Behavior }\end{array}$ & $\begin{array}{l}\text { Visual Learning, } \\
\text { Discussion }\end{array}$ & 2 hours & Pictures and Video \\
\hline 3 & First Puppet Show & Story & 2 hours & Short story, hand puppet, puppet stage \\
\hline 4 & $\begin{array}{l}\text { Second Puppet } \\
\text { Show }\end{array}$ & Story & 2 hours & $\begin{array}{l}\text { Short story, hand } \\
\text { puppet, puppet stage }\end{array}$ \\
\hline 5 & Third Puppet Show & Story & 2 hours & Short story, hand puppet, puppet stage \\
\hline 6 & Posttest & Observation & 8,5 hours & Observation sheet, handycam, writing tools \\
\hline
\end{tabular}

In this research, the researcher built internal validity to prove the causal relation between independent and dependent variables. The researchers controlled the factors affecting internal validity including: proactive history; instrumentation effect; participant's effect. To measure reliability, inter-rater reliability was applied. Data analysis using Statistical Packages for Social Science (SPSS) by non-parametric test (Wilcoxon Signed Rank Test).

This non parametric test (Wilcoxon Signed Rank Test) was applied to measure the significance of differences between two ordinal scaled paired data groups or interval but not normally distributed (Hidayat, 2014). This test was applied to see whether there is a difference between pretest and post test scores. If there is a difference between the score of pretest and posttest, thus puppet show media affects the declining bullying behavior. Otherwise, if there is no difference between the pretest and post test scores, therefore the puppet show does not affect the declining bullying behavior.

\section{RESULT}

The results of reliability test for bullying behavior rating scale is 0,958 (Table 2). This reliability value is in high category and is feasible to be used in the research.

Table 2

Reliability Test Result Reliability Statistics

\begin{tabular}{|r|r|}
\hline $\begin{array}{c}\text { Cronbach's } \\
\text { Alpha }\end{array}$ & N of Items \\
\hline .958 & \\
\hline
\end{tabular}

Data analysis results show there is a quite significant decreasing mean in posttest compared to pretest. Mean pre-test of physical bullying behavior is 11,2222, decreased to 3,6667 in post-test (Table 3). The declining mean in posttest signified the declining physical bullying behavior intensity done by subject after the treatment.

Table 3

The Mean Differences of Pre-test and Post-test for Physical Dimension

\begin{tabular}{|l|l|l|c|c|c|}
\hline & N & Mean & $\begin{array}{c}\text { Std. } \\
\text { Deviation }\end{array}$ & Minimum & Maximum \\
\hline $\begin{array}{l}\text { Physical } \\
\text { PRE-TEST }\end{array}$ & 9 & 11.2222 & 6.11919 & 5.00 & 22.00 \\
\hline $\begin{array}{l}\text { Physical } \\
\text { POST-TEST }\end{array}$ & 9 & 3.6667 & 1.65831 & 1.00 & 6.00 \\
\hline
\end{tabular}

The next data is the amount of verbal bullying behavior intensity. The results show the decreasing mean in posttest compared to that in pre-test. Mean of pretest is 8,1111 decreased to 2,2222 in posttest (Table 4). The declining mean in posttest signifies the declining verbal bullying behavior intensity by subjects after the treatment.

Table 4

The Mean Differences of Pretest and Posttest for Verbal Dimension

\begin{tabular}{|l|c|c|c|c|c|}
\hline & $\mathbf{N}$ & Mean & $\begin{array}{c}\text { Std. } \\
\text { Deviation }\end{array}$ & Minimum & Maximum \\
\hline $\begin{array}{l}\text { VERBAL PRE- } \\
\text { TEST }\end{array}$ & 9 & 8.1111 & 4.51233 & 3.00 & 15.00 \\
\hline $\begin{array}{l}\text { VERBAL POST- } \\
\text { TEST }\end{array}$ & 9 & 2.2222 & 1.09291 & 1.00 & 4.00 \\
\hline
\end{tabular}


The last data are the amount of psychological bullying behavior intensity. The results show that there is a decreasing mean in posttest compared to pre-test. The mean of pre-test is 3,7778 , decreased to 1,8889 in post-test (Table 5). The declining mean in post-test signifies the declining psychological bullying behavior intensity amount by subjects after the treatment.

Table 5

The Mean differences of Pre-test and Post-test for Psychological Dimension

\begin{tabular}{|l|c|c|c|c|c|}
\hline & N & Mean & $\begin{array}{c}\text { Std. } \\
\text { Deviation }\end{array}$ & Minimum & Maximum \\
\hline $\begin{array}{l}\text { Psychological } \\
\text { PRE-TEST }\end{array}$ & 9 & 3.7778 & 2.86259 & 1.00 & 11.00 \\
\hline $\begin{array}{l}\text { Psychological } \\
\text { POST-TEST }\end{array}$ & 9 & 1.8889 & 1.45297 & .00 & 5.00 \\
\hline
\end{tabular}

\section{DISCUSSION}

The research hypothesis stated that "puppet show is effective in decreasing the students bullying behavior intensity on children with special needs in inclusion school" is proved or accepted. This shows that puppet show affects the declining students bullying behavior. The intervention given is effectively proven from either descriptive or statistical analysis results, where the results show the significant score value differences, for physical bullying behavior intensity, pretest mean is 11.2222 and the posttest mean is 3,6667 whereas the pretest mean of verbal bullying behavior intensity is 8.1111 and the posttest mean is 2.222 and the last is the psychological bullying behavior intensity with pretest mean 3.7778 and the posttest mean is 1.8889 .

It means that puppet show is effective to lower the students' bullying behavior on the special need children at inclusive school. Psychoeducation module with puppet show media is arranged referring to the subjects' needs attained from the preliminary observation. The selection of the story content also has been adjusted to the condition and need of the experimental subjects.

The researcher chose psychoeducation with puppet show media as intervention to lower the students bullying behavior on children with special needs at inclusion school referring to several previous studies, where psychoeducation with puppet show proved effectively in managing problems related to bullying behavior on children with special needs. Psychoeducation with puppet show is aimed to give information or knowledge about children with special needs and bullying behavior in a more exciting way, thus research subjects will absorb information given easily and could lower bullying behavior intensity on students with special needs.

The success of this puppet show is due to the active roles of the participants. According to Goldstein (in Hidayati, 2012) the active involvement and learning experience could be the base of optimum learning transfer and not only as passive information. During the research process, the participants were quite active in expressing their opinions, answering questions as well as sharing stories. The enthusiasm of the participants was seen from their involvement in joining the research conducted for six days.

In psychoeducation activity with puppet show media, learning process occurred on subjects through visual and listening. Almost the same intervention was conducted by Pitre (2007) about using puppets for elementary school children to reduce stigma of people with psychological disorder, the results showed increasing comprehension of students about people with psychological disorders therefore lowering stigma of them. Moreover, in the research about psychoeducation using puppet show media found that subjects were not only see but also interacted directly in questions and answers thus increasing subject's knowledge.

The implementation of puppet show could increase the percentage of listening ability on children causing excitement to listen to the contextual story or information conveyed like the life around those children. Moreover, the children were enthusiastic in joining psychoeducation activity due to the usage of puppet media. This is as asserted by Dhieni (in Juliandri, 2015) that a story will be interesting to listen to if it is told by using realia.

The increasing knowledge shows that the puppet show media could be alternative media in conveying message or information. Message will not be conveyed successfully if the media used is not attractive for subjects. In order to make media attractive for subjects, especially children, media should be made very interesting as stated by Bandura (in Hergenhahn \& Olson, 2008) that in observational learning process, object should be attractive. The observational learning asserted by Bandura (in Santrock, 2009) stated that shaping or changing behavior conducted through or by observation with model or example of puppet show with the story of children with special needs and bullying behavior.

There are four process of observational learning of Bandura (in Santrock, 2009), first is attention. The definition of attention is the focusing or concentration of all individual activities aimed at one or a cluster of objects (Walgito, 2008). In this research the use of puppet media is aimed to attract attention of the subjects by giving stories about children with special needs and bullying behavior and funny puppets characters. The subjects' attention in this research was very well, children were attracted to the puppet thus when this research took place their attentions were on the puppet show.

Then on the second process, which is memory. When stimulus was given there was attention to those stimuli which could be accepted or integrated by sensory devices, then information process to memory occurred thus children could remember. Memory is physical ability for learning, retention and remembering the past (Walgito, 2008).

According to Fathan (2013) when a child remembers there are three basic process in memory formation which are encoding, storage, retrieval. In encoding, subject will encode information into memory, in this matter subject listens to the guidance of the experimenter. One of the indicators in encoding process is attention, repetition, deep process, elaboration, constructing image and arranging. Repetition in this research is used as encoding so that children could be able to absorb information given. After children absorb the information, that will be sent to sensory storage as the result of temporary sensory.

The impact of this repetition form given, the information of temporary sensory result will go to short term memory or human conscious center where there are 
thinking, information and experience which later could be sent to long-term memory through recall. The repetition of treatment given to subjects continuously makes subject do recalling to all that have been given in this matter is information about children with special needs and bullying behavior. Giving information repeatedly and subject's recall could be saved in long-term memory thus the subject knowledge about children with special needs and bullying behavior could be saved.

In the third step which is production, subjects paid attention and remember information conveyed during the psychoeducation by puppet show media and gave knowledge and understanding, then subjects would try to apply the knowledge acquired by not doing the bullying behavior on their friends with special needs, because from the information, bullying behavior is negative behavior and each man is different.

In the final step, motivation, children frequently followed what was said or did by the model, saving information in the memory, but not motivated. Therefore, during the study, the researcher also gave reinforcement in form of words, for example when subjects did good behavior by not bullying their friends by praising this behavior. This made subjects lowering their bullying behavior on children with special needs and also able to accept and befriend students with special behavior.

The process set showed that psychoeducation using puppet show media could lower students bullying behavior intensity on children with special needs as shown by several research using puppet media as used by Synovitz (1999) which used puppet for school health program coordinated to increase positive health behavior.

Then the research by Brits (2014) presented the nano technology lesson for toddlers by using puppet. In that research, using puppet media helped to explain the lessons about nanotechnology which is difficult to be more excited and easier. Moreover, Nasirzadeh and Roshan (2010) and Homaei et al (2009) have considered storytelling with toys or dolls was effective in reducing aggression and increasing the compatibility of children.

\section{CONCLUSIONS}

Based on the results of the research about the effectiveness of puppet show to lower the students' bullying behavior on children with special needs at inclusion school, it could be concluded as follows: the results of the research show that there are differences of bullying behavior intensity in pretest and posttest meaning that puppet show media is effective in lowering the students bullying behavior on children with special needs at inclusion school.

\section{REFERENCES}

[1] Anggraini, R. R. (2013 ). Persepsi Orang Tua terhadap Anak Berkebutuhan Khusus (Deskriptif Kuantitatif di SDLBN No.20 Nan Balimo Kota Solok). Jurnal Ilmiah Pendidikan Khusus, 258-265.

[2] Astuti, P. R. (2008). Meredam Bullying (3 Cara Efektif Menanggulangi Kekerasan pada Anak).

[3] Jakarta : Grasindo.

[4] Braga, G.C; Silveira, E.M; Coimbra, V.C.C; Porto, A.R. (2011). Promotion in Mental Health; Nursing Creating and Intervening with Children's Stories. Revista Gaucha de
Enfermagem, 32: 121-8

[5] Brits, J. (2014). Exploring The Use of Puppet Shows in Presenting Nanotechnology Lessons in Early Childhood Education. International Journal for Cross-Disciplinary Subjects in Education , 1798-1803.

[6] Dunst, C. J. (2012). Effects of Puppetry on Elementary Students' Knowledge of and Attitudes Toward Individuals with Disabilities. International Electronic Journal of Elementary Education, 451-457.

[7] Fathan, L. (2013). Psikologi Kognitif. Yogyakarta: Deepublish. Hargenhahn; Olson. (2008). Theory of Learning. Jakarta: Kencana.

[8] Hidayat, A. (2014, Juli 31). Tutorial Cara Uji Wilcoxon Signed Rank Test. Retrieved Desember 25, 2017, from https://www.statistikian.com/2014/07/tutorial-ujiwilcoxon-signed-rank-test.html.

[9] Hidayati. (2013). Pengaruh Pelatihan "Pengasuhan Ibu CERdaS" Terhadap Stres Pengasuhan Pada Ibu dari Anak Autis. Jurnal Psikoislamika, Vol 10 , 29-40.

[10] Homaei, R; Kajbaf, M; Siadat, S. (2009). The Effect of Telling Stories Upon Children's Adjustment. Psychol Stud; 5: 133-49.

[11] Nasirzadeh, R; Roshan, R. (2010). The Effect of Storytelling on Aggression in Six to Eight- Year Old Boys. Iranian J Psychiatr Clin Psychol; 16: 118-26.

[12] Pitre, N. (2007). The Use of Puppets with Elemantary School Children in Reducing Stigmatizing Attitudes Toward Mental Illness. Journal of Mental Health , 415429.

[13] Santrock, J. W. (2012). Life-Span Development Perkembangan Masa Hidup Edisi Ketigabelas Jilid I . Jakarta: Penerbit Erlangga .

[14] Sulianto, M. F. (2014). Media Boneka Tangan dalam Metode Bercerita untuk Menanamkan Karakter Positif Kepada Siswa Sekolah Dasar. Jurnal Pendidikan , 94-104.

[15] Supratiknya, A. (2016). Merancang Program dan Modul Psikoedukasi . Yogyakarta: Sanata Dharma University Press.

[16] Synovitz, L. B. (1999). Using puppetry in a coordinated school health program . journal of school health , 145147.

[17] Walgito, B. (2010). Pengantar Psikologi Umum . Yogyakarta: Penerbit Andi.

[18] Wiyani, N. A. (2012). Save Our Children from School Bullying. Yogyakarta: Ar-ruzz Media

[19] Juliandari. (2015). Penerapan Metode Bercerita dengan Media Boneka Tangan untuk Meningkatkan Kemampuan Menyimak Pada Anak. e-Journal PG PAUD Universitas Pendidikan Ganesha, 1-11. 